\title{
Influence of Drought Stress on Morphological Characters in Indian Wheat Cultivars
}

\author{
Lalit Kumar $^{1 *}$, Megha Singh $^{1}$ and Vaishali Arora ${ }^{2}$ \\ Sardar Vallabhbhai Patel University of Agriculture and Technology, Meerut; \\ College of Applied Education and Health Sciences, Meerut, India \\ *Corresponding author
}

Keywords

Drought stress, Drought resistance, Morphological characterization, polyethylene glycol, Reduced production and wheat

Article Info

Accepted:

07 September 2020 Available Online: 10 October 2020

\section{A B S T R A C T}

Crop growth, development and productivity are affected adversely by various abiotic stress in which drought is one major upcoming problem due to increasing global temperature. The study was conducted to understand the adaptation behaviour of the crop plant against drought-prone environment. This article describes morphological changes that occurred after treating seeds of 20 different Indian wheat cultivars with PEG-6000 in three different concentrations i.e. 10\%, $20 \%$ and $30 \%$ for inducing drought conditions. The observations were taken after sowing seeds in Randomized Block Designed field which resulted in reduced germination percentage, root length, shoot length, plant height, flag leaf area, length of spike, number of tillers per plant, number of spikelet per spike, number of grains per spike and thousand grain weights. The results showed that induced drought stress significantly reduced their value with increasing stress level. The germplasm HD2733 and K9107 show very less effect of induced drought stress and maintained their yield potential even after the third level of stress condition. This study may become helpful in searching drought tolerant genotypes for further breeding and biotechnological manipulations for generating novel and improved wheat variety.

\section{Introduction}

Researchers reported that climatic changes generate difficult conditions for producing needed quantity of the crop for fulfilling necessities of the population. Higher temperature scales straight-forwardly affects water bodies and create hindrances in agricultural affairs. Reduced plant production is the cause of environmental changes and alarming threats towards food security (Mickelbart et al., 2015). Abiotic stresses like drought, saltiness, heavy rainfall and extreme temperature shows adverse impacts on growth of plant, metabolism and physiology. These stressed climatic conditions results in floods, drought and high heat stroke (Bita and Gerats, 2013). Daryanto et al., in 2016 studied and 
analyzed previous research data from year 1980 to 2015 . They reported that wheat yield has reduced from $21 \%$ to $40 \%$ due to drought globally. Population around the world is hoped to reach nine billions by 2050, therefore, the turnout of crops should be increased by $40 \%$ in sectors that are expected to be drought prone upto 2025 (Pennisi, 2008). Wheat is massively affected by shifts in climatic conditions, therefore, abiotic stress like drought brought major decline in the productivity of especially wheat crops (Shao et al., 2005; Kirigwi et al., 2007; Huseynova and Rustamova, 2010). Continual drought occurrence that resulted due to change in weather condition will show reduced world's wheat productions which in turn do not provide justifiable agricultural production and supportable nutrition (Li et al., 2009; Mwadzingeni et al., 2016).

Cell division, cell enlargement and differentiation processes are directly related to genome, physiology, ecology, morphology, growth and development of the plant that are sensitized towards drought (Taiz and Zeiger, 2006). The harmful effects of drought are going to reach drastic increase, therefore, it is necessary to begin search for wheat genotypes which are tolerant to drought stress. It was studied by Anonymous in 2013 that all stages of plant life cycle are defense less against moisture stress; therefore, plants reaction towards drought depends upon the time span for which it is exposed to a specific potency of moisture stress. It minimizes biomass, number of tillers, grains per spike, size of grain etc. (Bukhat, 2005).

\section{Materials and Methods}

\section{Collection of plant materials}

Seeds of twenty wheat cultivars were obtained from Seed Production Unit, Department of Genetics and Plant Breeding,
Sardar Vallabhbhai Patel University Of Agriculture and Technology, Meerut, were used in this study. The cultivars are: K-802, K-1256, K-607, K-9107, K-6525, K-9423, DBW-71, DBW-16, DBW-17, MP-4010, MP3336, PBW-226, PBW-373, PBW-590, PBW71, PBW-533, HD-2733, HD-3086, HD-3095 and HD-2864.

\section{Field trial}

The experiment was conducted at field laboratory of Department of Agriculture Biotechnology, Sardar Vallabhbhai Patel University of Agriculture and Technology, Meerut, U.P., during rabi season of two consecutive years (2015-16 and 2016-17). The seeds of all genotypes were treated with three concentrations $(10 \%, 20 \%$ and $30 \%)$ of Poly Ethylene glycol (PEG) for 48 hours in Petri plates in three replications (T1-10\% PEG; T2-20\% PEG; T3- 30\% PEG) along with control and allow them to germinate. After 48 hours, the seedlings were transferred to field and maintained under optimum conditions till maturity. The Experiments was conducted under Randomized Block Design (RBD) throughout the study. In each block 25 seeds were spreaded randomly. Every replication was tagged with their genotype name and PEG concentration (10\%, 20\% and $30 \%)$. After transferring the seeds to the field was only irrigated in excessively dry condition for maintaining the stress; otherwise it was depended on rain water.

The crop was observed for various morphological characters (germination percentage, root length, shoot length, plant height, flag leaf area, length of spike, number of tillers per plant, number of spikelet per spike, number of grains per spike and thousand grain weights). The observations were recorded from each introgression lines in each replication at different growth stages. 


\section{Morphological characterization}

\section{Pre-harvest characters}

\section{Germination percentage}

After transferring the seeds to pots and field they were kept under observation from Day 1 to Day 10 for recording total germination occurred within 10 days after sowing. The germination percentage was calculated by using following formula:

Germination Percentage $=$

no.of seeds germinated

Total no of Seeds Germinated X 10

\section{Root length}

Root length was measured in centimeter after 10 days of germination.

\section{Shoot length}

Shoot length was measured in centimeter after 10 days of germination.

\section{Number of tillers}

Wheat seedling of different cultivars in their early stages of growth show marked difference in their growth habits. The number of tillers is directly related to the yield of plant and was recorded after 20 days after anthesis.

\section{Plant height}

Plant height was measured from the plants grown in fields and expressed in centimeters from bases of the plant to the tip of the spike (excluding awns) 20 days after anthesis.

\section{Flag leaf area}

It is Length and width of flag leaf measured 20 days after anthesis.

\section{Post-harvest characters}

\section{Length of spike}

Ear length was measured in centimeter from tips of apical spikelet (excluding awns) to the bases or collar of ear.

\section{Grain per spike}

Grains were counted from plant taken from each block.

\section{Spikelet per spike}

Number of spikelet present on spike was counted per genotype and their respective treatments.

\section{0 grain weight}

Weight of thousand seeds expressed in grams.

\section{Results and Discussion}

During both cropping season (2015-16; 201617), the wheat genotypes were evaluated for various morphological characters by recording three reading for one sample per block. The data analysis was conducted on the mean values of both seasons. For evaluating the effect of induced drought stress with increasing PEG levels the data was analysed with the help of coefficient of variance (C.V.) to calculate the degree of variation from one data series to another, F-probability test (Fprob) for evaluating significant difference in different population of treated plants, standard error of the mean (S.E.M.) and critical difference (C.D.)is used to compare means of different treatments that have an equal number of replications. C.D. $1 \%$ denoted $99 \%$ i.e. only 1percent chance of difference occurred due to natural variation and C.D. 5\% denoted $95 \%$ i.e. only 5 percent chance of difference occurred due to natural variation. On the basis of this analysis the graphs are 
plotted showing variability in values for various morphological parameters.

\section{Pre harvest characters}

\section{Germination percentage}

The seeds of all 20 varieties were treated with PEG (polyethylene glycol) with control in petri plates for 48 hours for imposing drought stress. After the treatment the seeds were transferred to the field. The seeds were observed regularly upto 10 days and data of seed germination was recorded at every 24 hours. The germination percentage was calculated and the result is presented in Table 1. The graphical representation of data is also shown in figure $1 \mathrm{~A}$. The seeds of all variety took different time to germinate as well as show different percent of seed germination. The result showed that after 10 days of sowing the maximum seeds were germinated. After 10 days the genotype HD2733 and PBW373 shows the $100 \%$ seed germination under control condition. The genotypes K6525 and MP4010 shows 88\% and 89\% seed germination respectively. The rest of the genotypes show more than 90\% seed germination. However the germination percentage was found to be decreased with increasing concentration of polyethylene glycol from 0 to $30 \%$. Under imposed drought stress, the genotype HD2733 showed highest seed germination $90 \%, 84 \%$ and $80 \%$ at stress level T1 (10\% PEG), T2 (20\% PEG) and T3 (30\%PEG) respectively. The genotype MP3336 showed lowest seed germination $60 \%$ at level $\mathrm{T} 1$ (10\% PEG), the genotype K802 showed lowest seed germination $54 \%$ at level T2 (20\% PEG) and the genotype DBW71 showed lowest seed germination $34 \%$ at level T3 (30\% PEG).

\section{Shoot length}

To evaluate the effect of drought on shoot length, five plantlets after 15 days of growth were randomly selected from control and three level of PEG treatment of each genotype. The shoot length was measured in centimeters from the base of root to the tip of the seedlings. The data of shoot length during crop season 2015-16 and 2016-17 was recorded and their mean is shown in Table 1; Fig. 1B. As the table shows, variation was observed in the shoot length in control and under imposed drought stress. Among control plants the maximum shoot length was $20.95 \mathrm{~cm}$ in $\mathrm{K} 9423$ which is decrease to $16.2 \mathrm{~cm}$ at $\mathrm{T} 1,13.45 \mathrm{~cm}$ at $\mathrm{T} 2$ and $12.6 \mathrm{~cm}$ at T3. Whereas the lowest shoot length in control plants was $14.53 \mathrm{~cm}$ in DBW16 which is further decrease to $14.2 \mathrm{~cm}$ at $\mathrm{T} 1,14.60 \mathrm{~cm}$ at $\mathrm{T} 2$ and $9.25 \mathrm{~cm}$ at $\mathrm{T} 3$. Overall, under imposed drought stress condition at $\mathrm{T} 1$ the maximum shoot length was $17.95 \mathrm{~cm}$ in genotype HD2733 and the minimum shoot length was $10.65 \mathrm{~cm}$ in genotype K6525. Likewise at T2 and T3 level of stress condition the maximum shoot length was $19.30 \mathrm{~cm}$ in genotype HD2733 and $17.2 \mathrm{~cm}$ in HD2733 respectively. Whereas the minimum shoot length under T2 and T3 was recorded as $8.20 \mathrm{~cm}$ and $7.15 \mathrm{~cm}$ in genotype K6525 and genotype PBW533 respectively. Variation in shoot length was observed in both control and treatment in different wheat genotypes. However the shoot length was found to be reducing after the treatment of polyethylene glycol. The shoot length was negatively correlated with yield hence the genotypes show lesser shoot length seems to more useful in reference to this character.

\section{Root length}

Root length is also a crucial factor for understanding the development of plant. To study this character, after 15 days of germination five plants were randomly selected from each variety and the data was recorded. The averaging of this will consider for final analysis of the character. Variation in root length was observed in both control and 
treatment in different wheat genotypes which is shown in Table 1; Fig. 1C. As the table shows, among control plants the root length varies from a higher value of $3.48 \mathrm{~cm}$ in K9107 to lower value $1.88 \mathrm{~cm}$ in DBW16 genotype. At T1 level, the highest root length was $3.05 \mathrm{~cm}$ in genotype $\mathrm{K} 9107$, whereas the minimum root length was $1.53 \mathrm{~cm}$ in the genotype DBW16. Under stress level T2 and $\mathrm{T} 3$ the maximum root length was recorded in genotype HD2733 $(2.60 \mathrm{~cm})$ and $(2.33 \mathrm{~cm})$ respectively. Whereas the genotype PBW226 showed the minimum root length $(1.43 \mathrm{~cm})$ under stress level T2 and the genotype PBW71 showed the minimum root length $(1.21 \mathrm{~cm})$ under stress level T3. In general the root length is decreases as the stress level increases from $5 \%$ to $10 \%$ and $15 \%$ of PEG treatment.

\section{Plant height}

Plant height has a contribution in the increase of competitiveness to weeds, on the other hand it also increase the tendency to the lodging. Hence it is important character to study. For this purpose, five plants were randomly selected from all three treatments of each variety and the data was recorded. Plant height was recorded in $\mathrm{cm}$ in all control and treatment plants at the time of maturity when the chlorophyll is completely disappear. Variations were observed in the plant height during the crop season 2015-16 and 201617and their mean is shown in Table 2; Fig 2A. Significant variation in plant height was observed in control and treatment plant genotypes of wheat. As the result indicated the genotype HD3095 showed the maximum plant height $91.10 \mathrm{~cm}, 90.45 \mathrm{~cm}$ in control and T1respectively. Whereas the genotype DBW16 showed the maximum plant height $89.95 \mathrm{~cm}$ and $88.40 \mathrm{~cm}$ in $\mathrm{T} 2$ and $\mathrm{T} 3$ respectively. The minimum plant height was $68.10 \mathrm{~cm}, 65.00 \mathrm{~cm}, 64.30 \mathrm{~cm}$ and $58.90 \mathrm{~cm}$ in genotype DBW71 at control, T1, T2 and T3 respectively. However the genotype PBW533 also shows comparative less plant height in control and at all three level of stress. The plant height was negatively correlated with yield hence the genotypes show lesser plant height seems to more useful in reference to this character.

\section{Number of productive tillers per plant}

This number of tillers is related to final yield of plant, therefore important to record. The numbers of tillers per plants were noted at the time of maturity. The data was recorded from five plants of each variety and their mean of both years is shown in Table 2; Fig. 2B. As per the result presented in table, the highest numbers of productive tillers was 10.00 in genotype HD2733, K607 and K9107 under control condition. At T1 level of stress condition the maximum number of productive tillers was 9.5 in genotype HD2733 and K607. At level $\mathrm{T} 2$ and $\mathrm{T} 3$ the maximum number of productive tillers was 9.00 in genotype K607. On the other hand the genotype K1256, DBW16 and HD2864 shows 7.00 numbers of productive tillers in control plants and are seems to be comparatively less useful in terms of yield. Under imposed drought stress the number of tillers decreases as the stress increases. At stress levelT1, T2 and T3 the number of productive tillers reduces significantly as compared to control condition. At level T1, $\mathrm{T} 2$ and $\mathrm{T} 3$ the minimum number of productive tillers was 5.00 in MP3336, 4.50 in MP3336 and 4.50 in MP3336 respectively.

\section{Flag leaf area}

Leaf is the main part of plant photosynthesis which can directly affect the strength of photosynthesis. Under drought stress, leaf would protect water and improve the utilization rate of water in plant by reducing transpiration and loss of water. During grain 
filling transport of nutrients is initiated from the flag leaf into the developing grains. Drought stress can influence the senescence of flag area, causing drop in crop yield. Hence the flag leaf area is an important character to study the plant response under stress condition.

It is evident from the data that wide variation existed among the genotypes with respect to flag leaf area as shown in Table 3; Fig. 3A. The results indicated a significant decrease in the flag leaf area as the stress increases. The maximum flag leaf area was $27.39 \mathrm{~cm}^{2}$ in genotype K9107under control condition which is reduced to $26.23 \mathrm{~cm}^{2}$ at $\mathrm{T} 1,26.04 \mathrm{~cm}^{2}$ at $\mathrm{T} 2$ and $23.73 \mathrm{~cm}^{2}$ at $\mathrm{T} 3$ level of stress treatment. On the other hand the minimum flag leaf area was $14.28 \mathrm{~cm}^{2}$ in genotype MP4010 which is further reduced to $12.07 \mathrm{~cm}^{2}$ at $\mathrm{T} 1,11.92 \mathrm{~cm}^{2}$ at $\mathrm{T} 2$ and $10.58 \mathrm{~cm}^{2}$ at $\mathrm{T} 3$ level of stress treatment. At the T3 level of stress treatment the maximum flag leaf area was $24.51 \mathrm{~cm}^{2}$ in genotype HD2733 and the minimum flag leaf area was $9.75 \mathrm{~cm}^{2}$ in genotype DBW17.Overall, the plant leaf area was found to be decreased with increasing concentration of polyethylene glycol from 0 to $30 \%$.

\section{Length of spike}

The length of spike is directly contributed to yield component. Therefore the spike of five different plant of same variety was measured for their length and the data is shown in table 3; Fig. 3B.

The result indicated that the maximum length of spike was $20.41 \mathrm{~cm}$ in genotype HD2733 under control condition which is reduced to $20.28 \mathrm{~cm}$ at T1 level, $19.68 \mathrm{~cm}$ at T2 level and $19.45 \mathrm{~cm}$ at T3 level. However, the minimum length of spike was $8.40 \mathrm{~cm}$ in MP4010which is further reduced to $8.40 \mathrm{~cm}$ at $T 1,8.00 \mathrm{~cm}$ at $\mathrm{T} 2$ and $7.65 \mathrm{~cm}$ at $\mathrm{T} 3$ level of stress treatment.
The length of spike was found to be reduces as the stress level increases. The minimum length of spike was $8.45 \mathrm{~cm}$ in genotype MP4010 which is further reduced to $8.4 \mathrm{~cm}$ at $\mathrm{T} 1,8.00 \mathrm{~cm}$ at $\mathrm{T} 2$ and 7.65 at $\mathrm{T} 3$ level of stress treatment.

\section{Post-harvest characters}

\section{Spikelets per spike}

The number of spikelets per spike is also directly related to plant yield. The number of spikelet was counted in 10 spikes collected from five different plants of each variety and average of them was considered for further analysis (Table 4; Fig. 4A). The maximum number of spikelet was recorded 22 in genotype K9107 under control condition and decrease to 21 at $\mathrm{T} 1,19$ at $\mathrm{T} 2$ and 17 at $\mathrm{T} 3$ level of stress treatment.

The minimum number of spikelet was recorded 11 in genotype MP3336which is further reduced to 10 at T1, T2 and 8 at T3 level of stress treatment. The maximum number of spiklet was 18 in genotype HD2733 at T3 level of stress treatment. Overall the genotype HD2733, PBW226, K9107, K802 and K9423 are seems to be good in terms of yield as they produce relatively higher number of spiklet per spike under control condition.

\section{Seeds per spike}

Seeds per spike is direct measure of yield/plant and also economically important. The seeds per spike was counted and found to vary from genotype to genotype as shown in result (Table 4; Fig. 4B). Under control condition the maximum number of seeds per spike was recorded 65.00 in genotype HD2733 and is decreases to 60.00, 55.50 and 53.00 as the stress increases from $\mathrm{T} 1$ to $\mathrm{T} 2$ and $\mathrm{T} 3$ respectively. 
Table.1 Characters of wheat genotype observed at Seedling stage

\begin{tabular}{|c|c|c|c|c|c|c|c|c|c|c|c|c|}
\hline \multirow{2}{*}{$\begin{array}{l}\text { Wheat } \\
\text { Genotype }\end{array}$} & \multicolumn{4}{|c|}{ Germination Percentage } & \multicolumn{4}{|c|}{ Shoot Length(cm) } & \multicolumn{4}{|c|}{ Root Length(cm) } \\
\hline & $\mathbf{C}$ & T1 & $\mathbf{T} 2$ & T3 & $\mathbf{C}$ & T1 & $\mathbf{T} 2$ & T3 & $\mathbf{C}$ & T1 & $\mathbf{T} 2$ & T3 \\
\hline K1256 & 95.00 & 76.00 & 65.00 & 48.00 & 16.65 & 17.60 & 13.95 & 12.30 & 2.53 & 2.38 & 2.16 & 1.85 \\
\hline HD3086 & 98.00 & 72.00 & 65.00 & 44.00 & 18.50 & 16.80 & 14.75 & 11.85 & 2.85 & 2.41 & 1.90 & 1.80 \\
\hline HD3095 & 94.00 & 82.00 & 71.00 & 62.00 & 14.95 & 13.90 & 13.95 & 9.40 & 2.80 & 2.58 & 2.08 & 1.61 \\
\hline DBW16 & 92.00 & 75.00 & 61.00 & 36.00 & 14.53 & 14.20 & 14.60 & 9.25 & 1.88 & 1.53 & 1.50 & 1.48 \\
\hline PBW590 & 97.00 & 74.00 & 66.00 & 42.00 & 19.90 & 16.95 & 18.30 & 15.20 & 3.11 & 2.46 & 2.40 & 1.81 \\
\hline PBW71 & 95.00 & 72.00 & 66.00 & 59.00 & 19.95 & 17.00 & 13.55 & 12.75 & 2.66 & 2.46 & 2.33 & 1.21 \\
\hline HD2864 & 92.00 & 82.00 & 74.00 & 55.00 & 17.25 & 15.15 & 13.15 & 12.90 & 2.48 & 2.46 & 2.10 & 1.30 \\
\hline DBW71 & 97.00 & 76.00 & 66.00 & 34.00 & 19.80 & 15.80 & 13.25 & 11.10 & 2.78 & 2.46 & 1.91 & 1.36 \\
\hline PBW226 & 94.00 & 75.00 & 61.00 & 47.00 & 20.90 & 16.25 & 16.25 & 12.05 & 2.41 & 2.08 & 1.43 & 1.56 \\
\hline MP3336 & 92.00 & 59.00 & 42.00 & 35.00 & 18.10 & 15.30 & 16.40 & 10.95 & 2.41 & 2.26 & 1.98 & 1.55 \\
\hline К9107 & 97.00 & 89.00 & 78.00 & 71.00 & 17.96 & 15.65 & 15.45 & 13.60 & 3.48 & 3.05 & 2.48 & 1.96 \\
\hline К607 & 94.00 & 80.00 & 64.00 & 53.00 & 17.40 & 14.40 & 14.30 & 8.30 & 2.583 & 2.33 & 2.03 & 1.73 \\
\hline DBW17 & 90.00 & 71.00 & 60.00 & 38.00 & 15.65 & 15.95 & 15.00 & 13.85 & 2.26 & 2.23 & 1.70 & 1.30 \\
\hline K6525 & 88.00 & 78.00 & 65.00 & 49.00 & 18.60 & 10.65 & 8.20 & 7.65 & 2.93 & 2.48 & 2.35 & 1.63 \\
\hline K802 & 96.00 & 62.00 & 53.00 & 37.00 & 15.25 & 14.90 & 13.10 & 11.60 & 2.71 & 2.36 & 2.10 & 1.63 \\
\hline MP4010 & 89.00 & 69.00 & 57.00 & 41.00 & 16.30 & 14.25 & 11.95 & 11.25 & 2.83 & 2.71 & 2.15 & 1.91 \\
\hline K9423 & 92.00 & 79.00 & 70.00 & 65.00 & 20.95 & 16.20 & 13.45 & 12.60 & 2.28 & 2.13 & 1.78 & 1.41 \\
\hline Gen. Mean & 53.250 & 36.800 & 26.200 & 17.800 & 17.78 & 15.25 & 14.14 & 11.71 & 2.69 & 2.39 & 2.03 & 1.62 \\
\hline C.V. & 3.658 & 11.154 & 11.045 & 17.761 & 2.479 & 7.616 & 7.603 & 10.837 & 10.862 & 15.745 & 17.732 & 21.041 \\
\hline F Prob. & 0.000 & 0.000 & 0.000 & 0.000 & 0.000 & 0.000 & 0.000 & 0.000 & 0.000 & 0.000 & 0.000 & 0.000 \\
\hline S.E.M. & 1.377 & 2.902 & 2.046 & 2.235 & 0.180 & 0.474 & 0.439 & 0.518 & 0.119 & 0.154 & 0.147 & 0.139 \\
\hline C.D. 5\% & 4.077 & 8.591 & 6.057 & 6.617 & 0.505 & 1.331 & 1.232 & 1.455 & 0.335 & 0.432 & 0.413 & 0.391 \\
\hline C.D. $1 \%$ & 5.573 & 11.743 & 8.279 & 9.045 & 0.669 & 1.763 & 1.632 & 1.926 & 0.444 & 0.572 & 0.546 & 0.518 \\
\hline
\end{tabular}

C-Control, T1-Treatment with PEG 10\%, T2- Treatment with PEG 20\%, T3- Treatment with PEG 30\% 
Table.2 Pre-harvest morphological characters of wheat genotypes, studied at maturity

\begin{tabular}{|c|c|c|c|c|c|c|c|c|}
\hline \multirow{2}{*}{$\begin{array}{l}\text { Wheat } \\
\text { Genotype }\end{array}$} & \multicolumn{4}{|c|}{ Plant Height (cm) } & \multicolumn{4}{|c|}{ No. Of Tillers } \\
\hline & C & T1 & $\mathbf{T} 2$ & T3 & C & T1 & $\mathbf{T} 2$ & T3 \\
\hline K1256 & 87.70 & 85.20 & 81.80 & 79.80 & 7.00 & 6.00 & 5.00 & 5.00 \\
\hline HD2733 & 81.51 & 80.45 & 79.95 & 85.00 & 10.00 & 9.00 & 7.00 & 7.00 \\
\hline HD3086 & 90.55 & 88.85 & 86.75 & 83.85 & 9.00 & 8.00 & 7.00 & 6.00 \\
\hline HD3095 & 91.10 & 90.45 & 79.70 & 75.20 & 7.00 & 7.00 & 6.00 & 6.00 \\
\hline DBW16 & 88.95 & 88.60 & 89.95 & 88.40 & 7.00 & 6.00 & 5.00 & 5.00 \\
\hline PBW533 & 72.13 & 71.70 & 69.60 & 65.95 & 9.00 & 8.00 & 6.00 & 7.00 \\
\hline PBW590 & 80.40 & 77.40 & 78.30 & 75.20 & 8.00 & 7.00 & 5.00 & 5.00 \\
\hline PBW71 & 81.95 & 79.10 & 75.60 & 74.75 & 9.00 & 7.00 & 6.00 & 4.00 \\
\hline HD2864 & 82.35 & 80.20 & 78.35 & 77.95 & 7.00 & 6.00 & 5.00 & 5.00 \\
\hline DBW71 & 68.10 & 65.00 & 64.30 & 58.90 & 8.00 & 7.00 & 6.00 & 5.00 \\
\hline PBW226 & 75.15 & 70.50 & 70.50 & 65.95 & 8.00 & 7.00 & 6.00 & 5.00 \\
\hline MP3336 & 84.35 & 80.30 & 77.85 & 75.65 & 5.00 & 5.00 & 4.00 & 4.00 \\
\hline K9107 & 80.50 & 78.15 & 77.95 & 76.10 & 10.00 & 8.00 & 7.00 & 6.00 \\
\hline PBW373 & 84.10 & 83.80 & 82.35 & 82.00 & 8.00 & 7.00 & 6.00 & 6.00 \\
\hline К607 & 78.35 & 75.40 & 74.85 & 68.85 & 10.00 & 9.00 & 9.00 & 9.00 \\
\hline DBW17 & 79.45 & 78.80 & 77.80 & 76.65 & 7.00 & 6.00 & 6.00 & 6.00 \\
\hline K6525 & 80.45 & 72.50 & 69.95 & 69.50 & 8.00 & 6.00 & 6.00 & 5.00 \\
\hline K802 & 79.10 & 78.65 & 76.75 & 75.30 & 9.00 & 6.00 & 6.00 & 5.00 \\
\hline MP4010 & 78.15 & 70.10 & 67.80 & 67.50 & 8.00 & 7.00 & 6.00 & 5.00 \\
\hline K9423 & 82.25 & 75.10 & 72.15 & 71.55 & 7.00 & 5.00 & 5.00 & 5.00 \\
\hline Gen. Mean & 81.33 & 78.51 & 76.61 & 74.70 & 8.258 & 7.317 & 6.325 & 5.742 \\
\hline C.V. & 0.335 & 1.408 & 3.630 & 2.027 & 4.005 & 12.532 & 13.937 & 15.495 \\
\hline F Prob. & 0.000 & 0.000 & 0.000 & 0.000 & 0.000 & 0.000 & 0.000 & 0.000 \\
\hline S.E.M. & 0.111 & 0.451 & 1.135 & 0.618 & 0.135 & 0.374 & 0.360 & 0.363 \\
\hline C.D. $5 \%$ & 0.312 & 1.267 & 3.187 & 1.736 & 0.379 & 1.051 & 1.010 & 1.020 \\
\hline C.D. $1 \%$ & 0.413 & 1.678 & 4.220 & 2.299 & 0.502 & 1.391 & 1.338 & 1.350 \\
\hline
\end{tabular}

Control, T1-Treatment with PEG 10\%, T2- Treatment with PEG 20\%, T3- Treatment with PEG 30\% 
Table.3 Pre- harvest morphological characters of wheat genotypes, studied at maturity

\begin{tabular}{|c|c|c|c|c|c|c|c|c|}
\hline \multirow{2}{*}{$\begin{array}{l}\text { Wheat } \\
\text { Genotype }\end{array}$} & \multicolumn{4}{|c|}{ Flag Leaf Area $\left(\mathrm{cm}^{2}\right)$} & \multicolumn{4}{|c|}{ Spike Length (cm) } \\
\hline & $\mathrm{C}$ & T1 & T2 & T3 & $\mathrm{C}$ & T1 & $\mathbf{T} 2$ & T3 \\
\hline K1256 & 23.09 & 23.01 & 22.80 & 22.48 & 16.30 & 16.18 & 13.53 & 11.31 \\
\hline HD2733 & 26.77 & 25.62 & 24.62 & 24.51 & 20.41 & 20.28 & 19.68 & 19.45 \\
\hline HD3086 & 25.28 & 18.14 & 17.74 & 15.49 & 15.30 & 15.05 & 13.70 & 12.35 \\
\hline HD3095 & 23.18 & 21.99 & 20.84 & 16.58 & 13.48 & 13.26 & 11.95 & 10.65 \\
\hline DBW16 & 15.38 & 14.29 & 14.34 & 12.34 & 14.63 & 14.36 & 13.10 & 10.91 \\
\hline PBW533 & 21.06 & 20.95 & 18.99 & 15.02 & 15.41 & 15.36 & 14.10 & 10.86 \\
\hline PBW590 & 20.68 & 19.59 & 17.29 & 16.90 & 19.10 & 18.61 & 18.41 & 16.05 \\
\hline PBW71 & 19.14 & 18.97 & 18.74 & 18.45 & 9.15 & 9.10 & 8.80 & 8.45 \\
\hline HD2864 & 25.85 & 23.69 & 20.43 & 18.29 & 16.80 & 16.80 & 15.40 & 15.20 \\
\hline DBW71 & 20.99 & 18.22 & 17.86 & 16.84 & 16.25 & 16.20 & 15.90 & 14.65 \\
\hline PBW226 & 17.16 & 16.09 & 12.97 & 11.82 & 18.90 & 18.85 & 18.50 & 18.25 \\
\hline MP3336 & 18.18 & 17.44 & 15.69 & 14.24 & 8.75 & 8.650 & 8.55 & 8.35 \\
\hline K9107 & 27.39 & 26.23 & 26.04 & 23.73 & 19.75 & 18.60 & 18.20 & 17.80 \\
\hline PBW373 & 15.19 & 15.14 & 14.53 & 14.05 & 15.15 & 14.15 & 14.90 & 12.05 \\
\hline К607 & 21.13 & 20.74 & 19.49 & 17.14 & 10.75 & 10.66 & 10.35 & 10.00 \\
\hline DBW17 & 15.34 & 14.14 & 12.69 & 9.75 & 14.15 & 14.15 & 13.05 & 12.85 \\
\hline K6525 & 24.63 & 24.40 & 22.24 & 19.94 & 10.55 & 10.20 & 9.75 & 9.15 \\
\hline K802 & 26.25 & 25.09 & 24.98 & 23.80 & 16.40 & 15.76 & 14.35 & 12.95 \\
\hline MP4010 & 14.28 & 12.07 & 11.92 & 10.58 & 8.45 & 8.40 & 8.00 & 7.65 \\
\hline K9423 & 22.74 & 18.54 & 15.54 & 12.29 & 17.05 & 16.85 & 15.20 & 13.85 \\
\hline Gen. Mean & 51.08 & 50.77 & 50.58 & 50.37 & 9.89 & 9.73 & 9.37 & 9.09 \\
\hline C.V. & 0.211 & 0.303 & 0.529 & 0.529 & 1.283 & 1.715 & 2.123 & 2.058 \\
\hline F Prob. & 0.000 & 0.000 & 0.000 & 0.000 & 0.000 & 0.000 & 0.000 & 0.000 \\
\hline S.E.M. & 0.044 & 0.063 & 0.109 & 0.109 & 0.052 & 0.068 & 0.081 & 0.076 \\
\hline C.D. 5\% & 0.123 & 0.177 & 0.306 & 0.305 & 0.145 & 0.191 & 0.228 & 0.214 \\
\hline C.D. $1 \%$ & 0.163 & 0.234 & 0.406 & 0.404 & 0.192 & 0.253 & 0.302 & 0.284 \\
\hline
\end{tabular}

C-Control, T1-Treatment with PEG 10\%, T2- Treatment with PEG 20\%, T3- Treatment with PEG 30\% 
Table.4 Post harvest morphological characters of wheat genotypes

\begin{tabular}{|c|c|c|c|c|c|c|c|c|c|c|c|c|}
\hline \multirow{2}{*}{$\begin{array}{l}\text { Wheat } \\
\text { Genotype }\end{array}$} & \multicolumn{4}{|c|}{ Spikelet / Spike } & \multicolumn{4}{|c|}{ Seed / Spike } & \multicolumn{4}{|c|}{1000 Grain Weight $(g)$} \\
\hline & $\mathbf{C}$ & T1 & $\mathbf{T 2}$ & T3 & $\mathbf{C}$ & T1 & $\mathbf{T} 2$ & T3 & $\mathbf{C}$ & T1 & $\mathbf{T} 2$ & T3 \\
\hline K1256 & 18.00 & 16.00 & 12.00 & 12.00 & 51.00 & 50.00 & 46.00 & 48.00 & 46.04 & 43.36 & 43.47 & 41.23 \\
\hline HD2733 & 19.00 & 19.00 & 19.00 & 18.00 & 65.00 & 60.00 & 55.50 & 53.00 & 38.70 & 35.55 & 34.03 & 33.08 \\
\hline HD3086 & 16.00 & 15.00 & 14.00 & 13.00 & 47.00 & 46.00 & 42.00 & 41.00 & 38.48 & 36.97 & 36.48 & 35.13 \\
\hline HD3095 & 15.00 & 15.00 & 14.00 & 12.00 & 51.00 & 47.00 & 44.00 & 44.00 & 39.12 & 38.08 & 36.60 & 35.58 \\
\hline DBW16 & 15.00 & 16.00 & 13.00 & 12.00 & 52.00 & 51.00 & 47.00 & 47.00 & 40.17 & 38.90 & 37.83 & 36.38 \\
\hline PBW533 & 18.00 & 17.00 & 16.00 & 13.00 & 48.00 & 48.00 & 46.00 & 44.00 & 41.92 & 40.18 & 37.50 & 36.07 \\
\hline PBW590 & 18.00 & 18.00 & 17.00 & 16.00 & 50.00 & 49.00 & 46.00 & 44.00 & 37.45 & 36.30 & 35.27 & 33.97 \\
\hline PBW71 & 12.00 & 12.00 & 11.00 & 11.00 & 46.00 & 45.00 & 41.00 & 41.00 & 39.93 & 38.10 & 35.53 & 34.67 \\
\hline HD2864 & 18.00 & 16.00 & 14.00 & 14.00 & 50.00 & 49.00 & 46.00 & 45.00 & 38.78 & 36.88 & 35.88 & 34.67 \\
\hline DBW71 & 18.00 & 18.00 & 18.00 & 16.00 & 55.00 & 52.67 & 50.00 & 50.00 & 40.47 & 37.03 & 35.53 & 33.70 \\
\hline PBW226 & 20.00 & 17.00 & 16.00 & 15.00 & 53.00 & 52.00 & 52.00 & 50.00 & 37.17 & 35.65 & 33.75 & 32.17 \\
\hline MP3336 & 11.00 & 10.00 & 9.00 & 8.00 & 52.00 & 51.00 & 46.00 & 47.00 & 39.17 & 37.23 & 36.30 & 34.85 \\
\hline K9107 & 22.00 & 21.00 & 19.00 & 17.00 & 58.00 & 55.00 & 50.00 & 45.00 & 35.97 & 34.67 & 33.18 & 32.37 \\
\hline PBW373 & 17.00 & 16.00 & 15.00 & 14.00 & 47.00 & 45.00 & 46.00 & 43.00 & 43.13 & 42.63 & 41.27 & 39.35 \\
\hline K607 & 12.00 & 12.00 & 11.00 & 10.00 & 56.00 & 54.00 & 52.00 & 48.00 & 40.70 & 39.12 & 37.33 & 36.40 \\
\hline DBW17 & 16.00 & 17.00 & 13.00 & 11.00 & 51.00 & 49.00 & 47.00 & 46.00 & 38.58 & 37.18 & 36.90 & 33.42 \\
\hline K6525 & 12.00 & 11.00 & 11.00 & 11.00 & 46.00 & 42.00 & 42.00 & 37.00 & 34.45 & 33.32 & 31.25 & 29.85 \\
\hline K802 & 19.00 & 19.00 & 16.00 & 14.00 & 50.00 & 46.00 & 47.00 & 46.00 & 31.63 & 31.38 & 30.65 & 28.33 \\
\hline MP4010 & 14.00 & 13.00 & 12.00 & 11.00 & 46.00 & 43.00 & 44.00 & 42.00 & 38.00 & 36.47 & 35.47 & 33.42 \\
\hline K9423 & 19.00 & 16.00 & 17.00 & 12.00 & 46.00 & 44.00 & 40.00 & 37.00 & 36.55 & 35.32 & 34.25 & 33.08 \\
\hline Gen. Mean & 21.367 & 18.842 & 17.492 & 15.867 & 51.200 & 49.058 & 46.775 & 45.217 & 38.82 & 37.22 & 35.92 & 34.39 \\
\hline C.V. & 4.275 & 11.076 & 13.121 & 15.447 & 1.571 & 3.100 & 3.672 & 2.698 & 2.63 & 1.78 & 2.35 & 1.59 \\
\hline F Prob. & 0.000 & 0.000 & 0.000 & 0.000 & 0.000 & 0.000 & 0.000 & 0.000 & 0.00 & 0.00 & 0.00 & 0.00 \\
\hline S.E.M. & 0.373 & 0.852 & 0.937 & 1.001 & 0.328 & 0.621 & 0.701 & 0.498 & 0.59 & 0.38 & 0.49 & 0.32 \\
\hline C.D. 5\% & 1.047 & 2.392 & 2.631 & 2.809 & 0.922 & 1.743 & 1.969 & 1.398 & 1.69 & 1.09 & 1.39 & 0.90 \\
\hline C.D. $1 \%$ & 1.386 & 3.167 & 3.483 & 3.720 & 1.221 & 2.308 & 2.606 & 1.851 & 2.26 & 1.46 & 1.86 & 1.21 \\
\hline
\end{tabular}

C-Control, T1-Treatment with PEG 10\%, T2- Treatment with PEG 20\%, T3- Treatment with PEG 30\% 


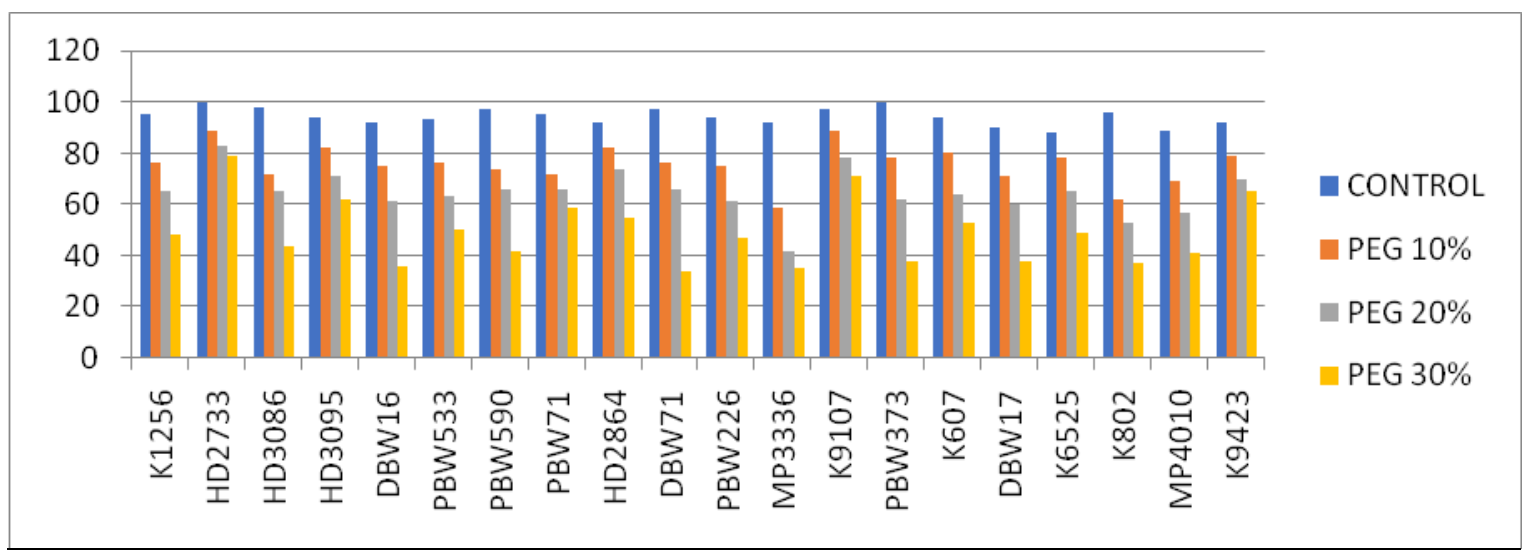

(A)

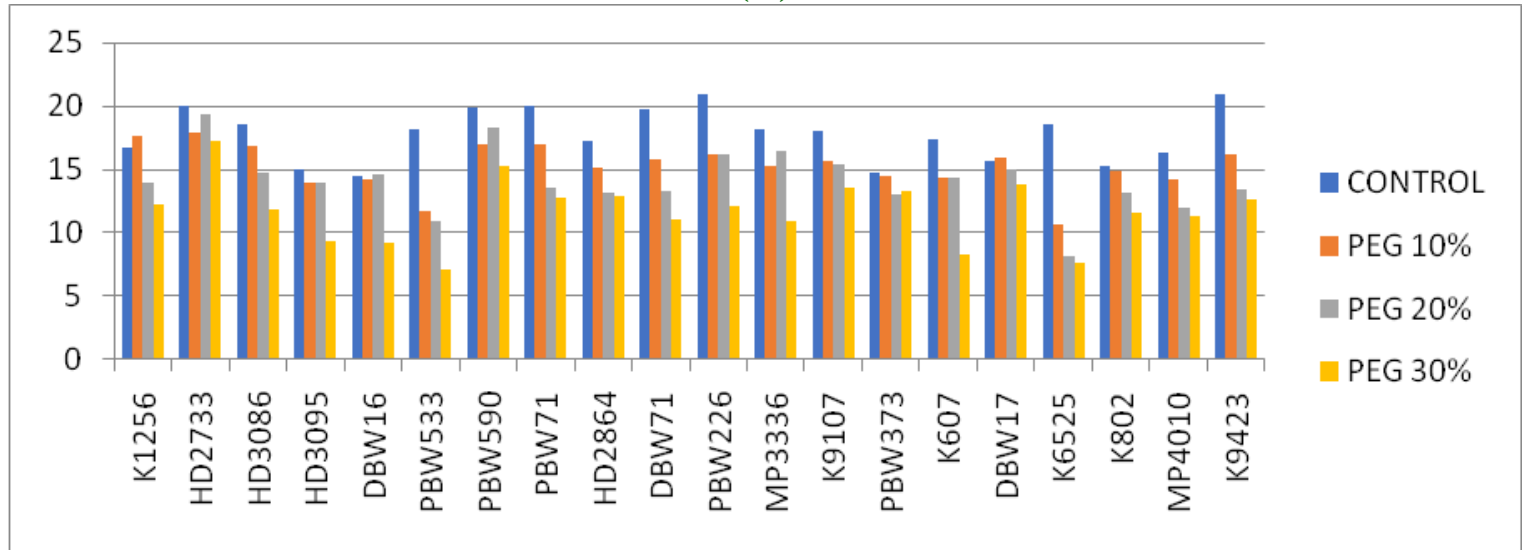

(B)

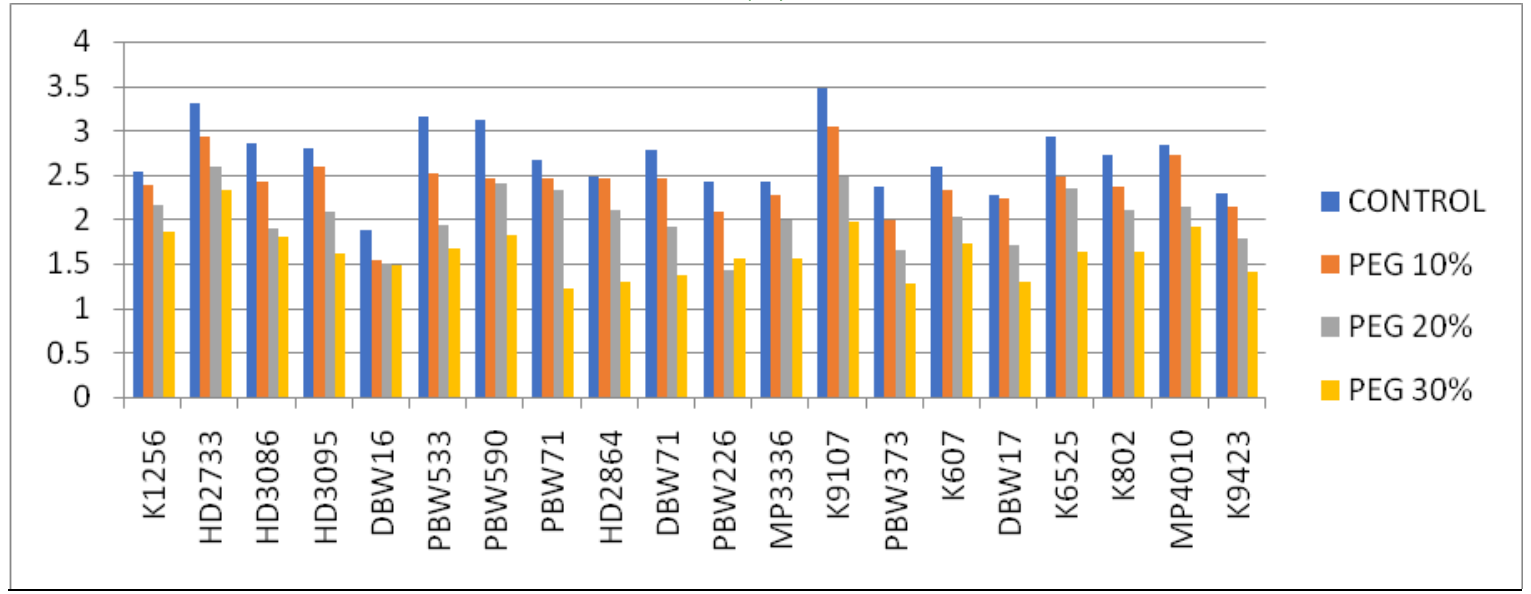

(C)

Figure.1 (A) Graphical representation of germination percentage of 20 wheat genotype, (B) Graphical representation of shoot length of 20 wheat genotype, (C) Graphical representation of root length of 20 wheat genotype. 


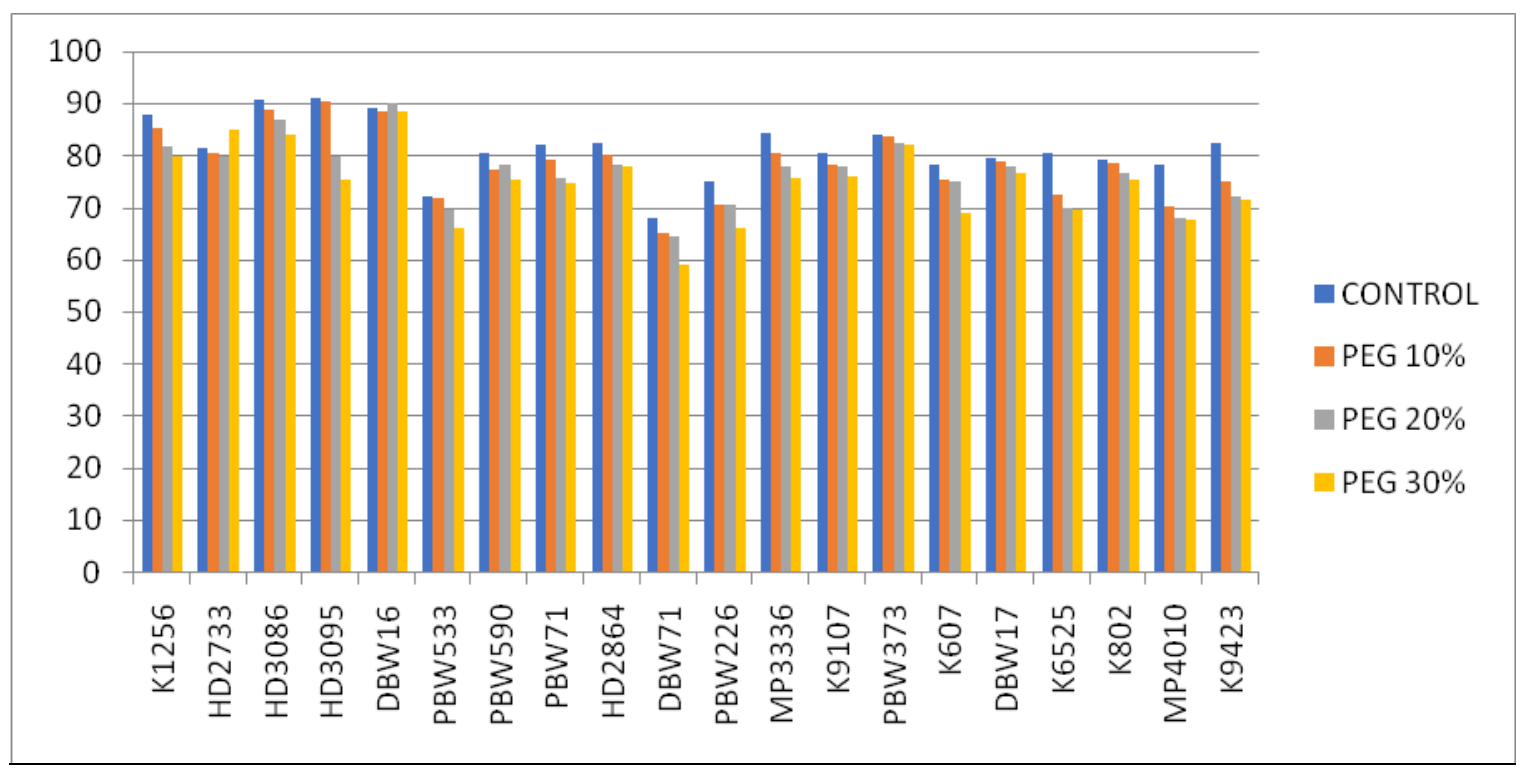

(A)

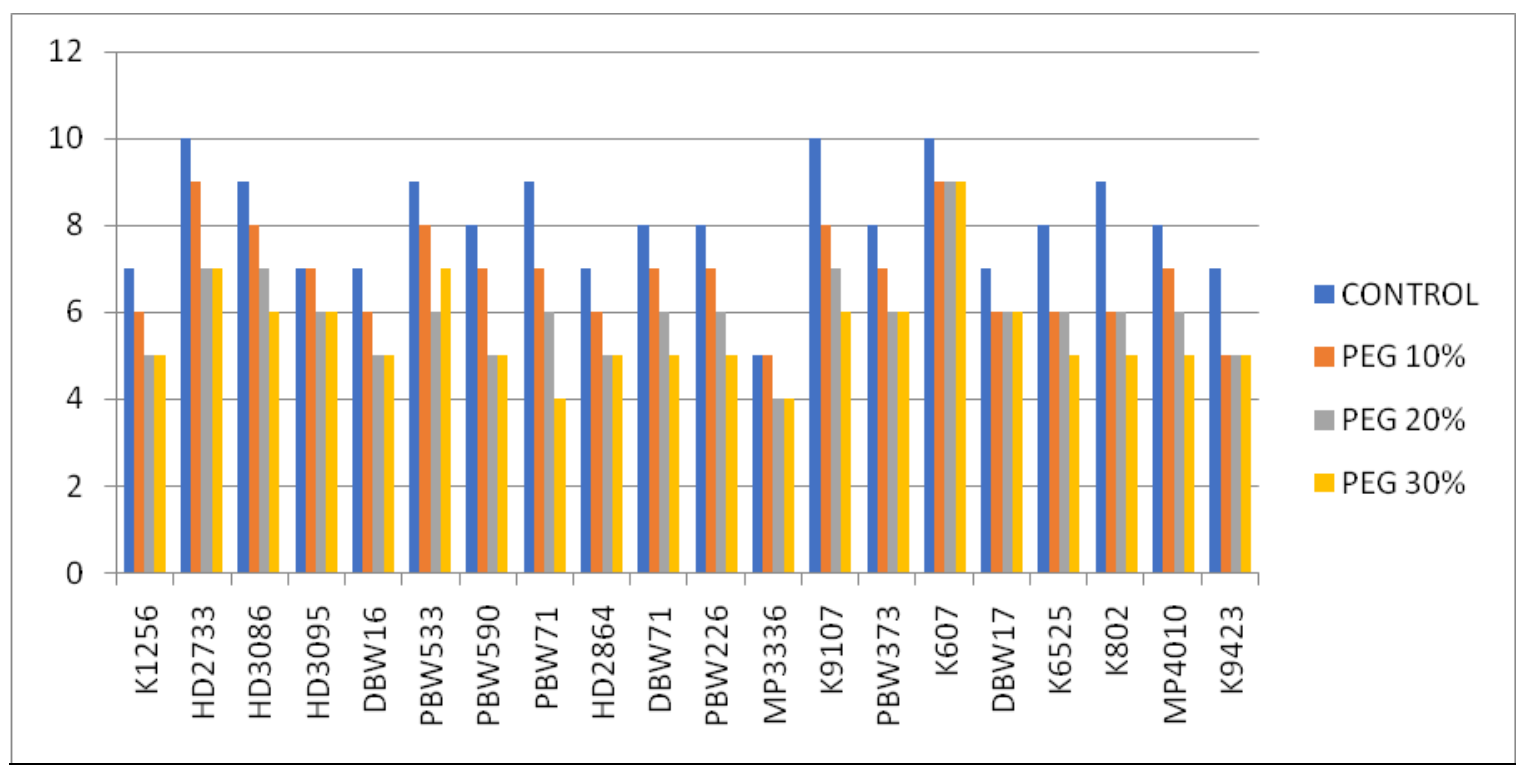

(B)

Figure.2 (A) Graphical representation of plant height of 20 wheat genotype, (B) Graphical representation of no. of tillers of 20 wheat genotype 


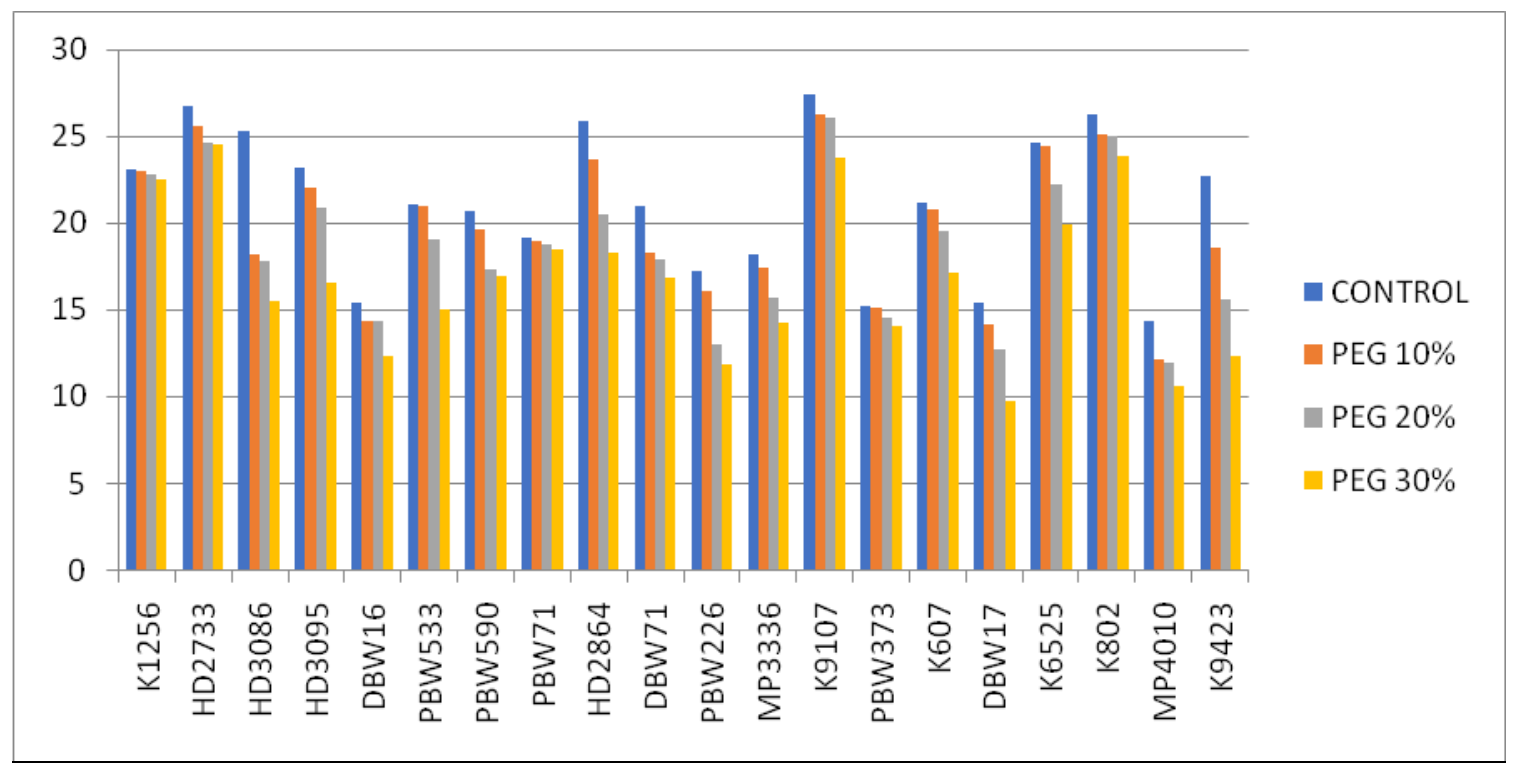

(A)

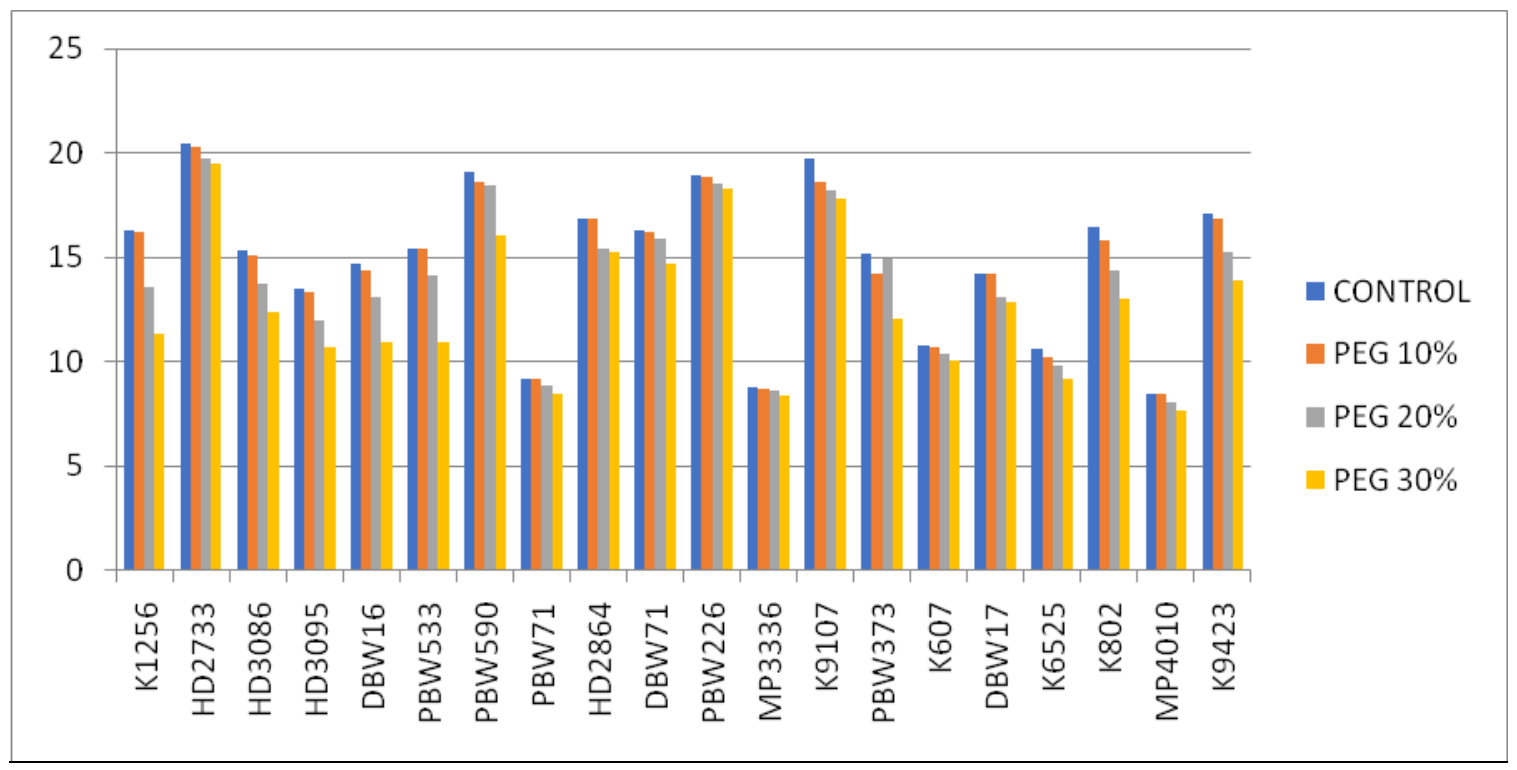

(B)

Figure.3 (A) Graphical representation of flag leaf area of 20 wheat genotype, (B) Graphical representation of spike length of 20 wheat genotype. 

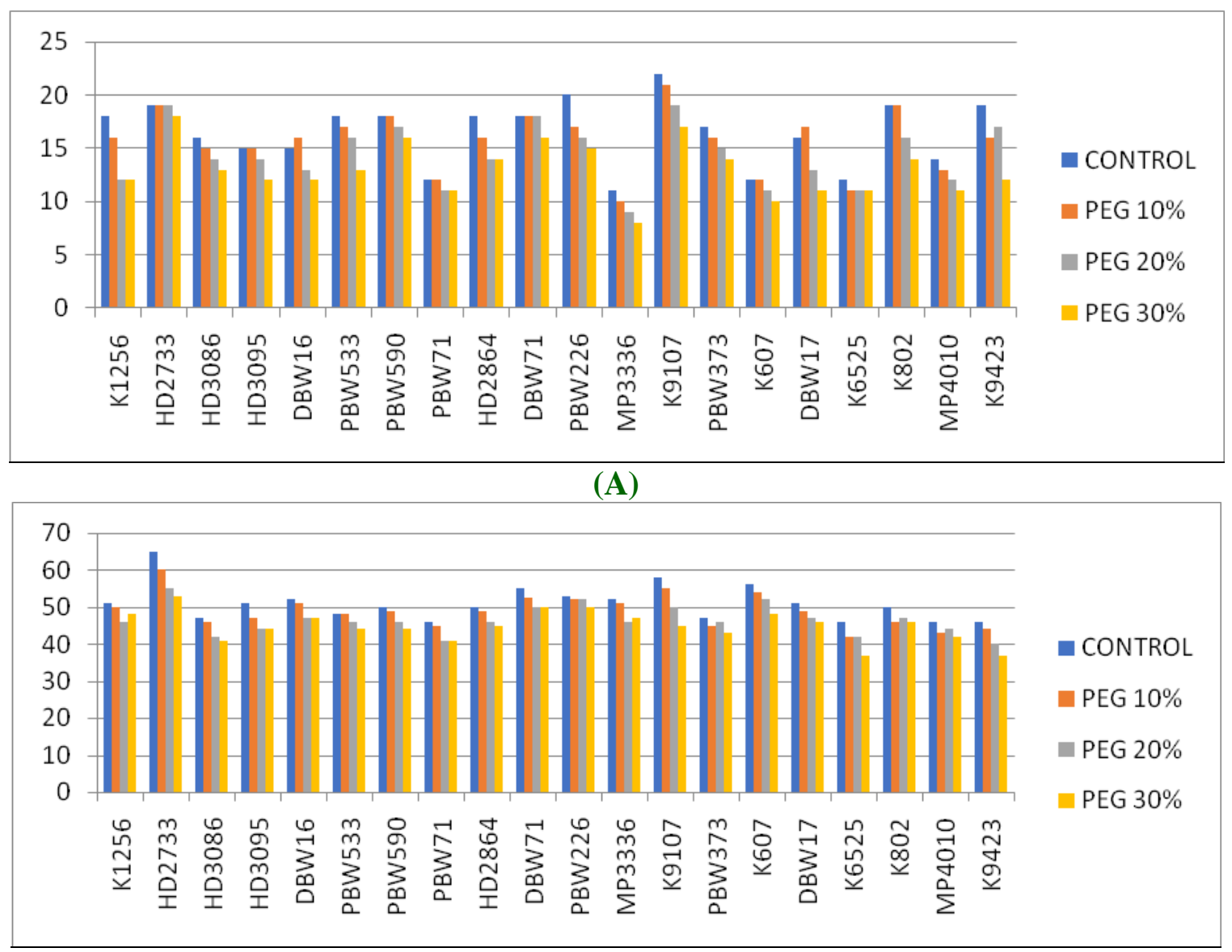

(B)

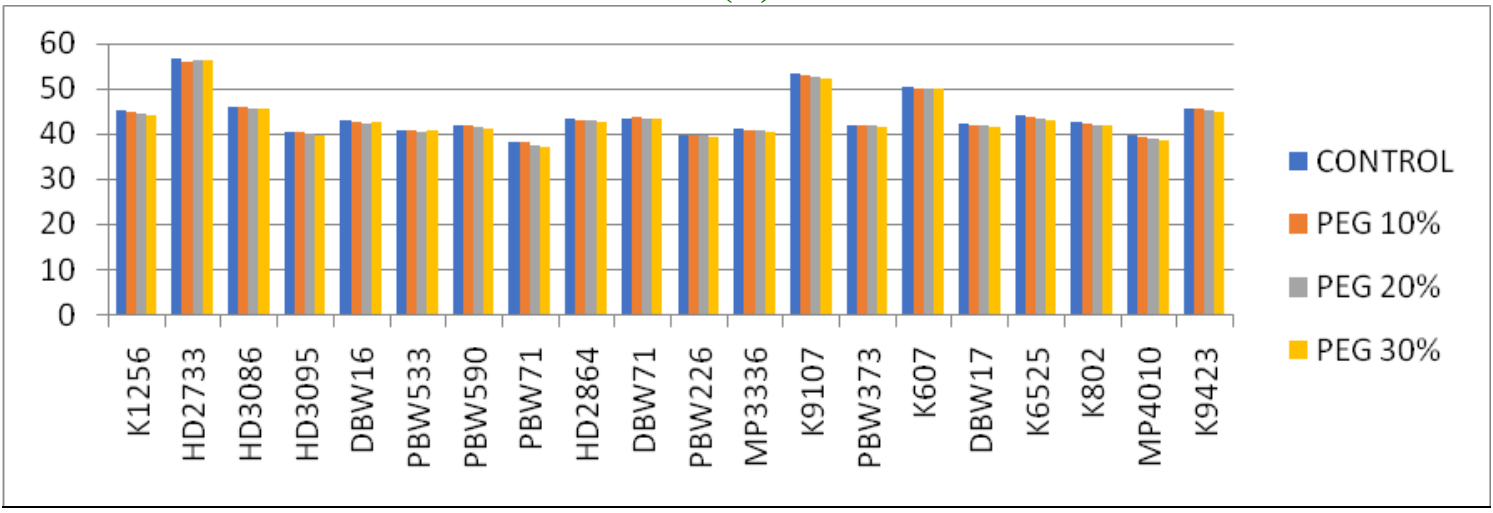

(C)

Figure.4 (A) Graphical representation of Spikelet Per Spike of 20 wheat genotype ,(B) Graphical representation of Grain Per Spike of 20 wheat genotype, (C) Graphical representation of 1000 Grain Weight of 20 wheat genotype 
However the genotype DBW71, K9107, K607 produces good number of seeds per spike i.e. $55.00,58.00$ and 56.00 respectively. The minimum number of seeds per spike was observed 46.00 in PBW71 and MP4010 under control condition which is further decreases to 45.00, 42.00, 41.00 in genotype PBW71 and $43.00,44.00,42.00$ in genotype MP4010 respectively as the stress increases from $\mathrm{T} 1$ to T3.

\section{0- grain weight}

The actual yield of the genotype is measured by thousand grain weight as the yield of plant depends upon size as well as weight of seeds of different wheat genotype. 1000 grain weight in all genotypes varies from $38.25 \mathrm{gm}$ in PBW71 to 56.70gm in HD2733 under control condition (Table 4; Fig. 4C). In addition to this the genotypes K9107 and K607also shows good amount of 1000grain weight i.e. 53.30gm and 50.20gm respectively. However, the grain weight was found to be reduced after the treatment of polyethylene glycol. Under stress condition, the test weight in genotype HD2733was reduced from $56.70 \mathrm{gm}$ in control to $56.10 \mathrm{gm}$, $56.45 \mathrm{gm}$ and $56.25 \mathrm{gm}$ as the stress increases from $10 \%, 20 \%$ and $30 \%$ of PEG treatment respectively. On the other hand, the minimum test weight was $38.25 \mathrm{gm}$ in genotype PBW71 under control condition which is further decreases to $38.10 \mathrm{gm}$ at $\mathrm{T} 1,37.40 \mathrm{gm}$ at $\mathrm{T} 2$ and $37.10 \mathrm{gm}$ at $\mathrm{T} 3$ level of stress treatment.

This study concludes in screening the wheat genotypes that are less affected by induced drought stress. These genotypes will be helpful in generating improved varieties with the help of breeding techniques and biotechnological approaches by screening the gene that made it less affected during drought stress. The morphological characters at preharvest stage were, plant height, flag leaf area and length of spike. All these characters except plant height are directly related to yield so they are economically important characters. Morphological characters of wheat genotypes exhibited high variability for the characters such as plant height, number of tillers, flag leaf area and spike length. In this reference the genotype DBW71 and PBW533 showed comparatively lesser plant height and seem to be good for high yield. The genotype HD2733, K607 and K9107 seem to be promising for high yield as they show good number of productive tiller, spike length and flag leaf area.

The post-harvest characters studied were number of tillers per plant, number of spikelet per spike, number of grains per spike and thousand grain weights. Moderate to high broad sense of variability were recorded for number of tillers per plant, number of spikelet per spike, number of grains per spike and thousand grain weights. The results showed that induced drought stress significantly reduced their value with increasing stress level. However the germplasm HD2733 and K9107 show very less effect of induced drought stress and maintained their yield potential even after the third level of stress condition. Thus, on the basis of various morphological characters it is concluded that higher yield of HD2733 and K9107 under non stress conditions might be on account of its higher yield potential. Therefore, these genotypes need to be utilized in future breeding program.

\section{References}

Ahmad M., Shabbir G., Minhas M. N. and Shah M.K.N. (2013). Identification of Drought Tolerant Wheat Genotype based on Seedling. Trait, J. Agric. 29. 21-27.

Alaei M., Zaefizadeh M., Khayatnezhad M., Alaei Z. and Alaei Y. (2010). Evaluation of germination properties of 
different durum wheat genotypes under osmotic stress. Middle East J. Sci. Res. 6. 642-646.

Anonymous. (2013). Wheat Scenario - A Snippet- e-newsletter from the Directorate of Wheat Research Karnal, Haryana India. pp. 1-6.

Bdr M.F. (2018). Growth and production of various wheat genotypes at various PEG concentration in hydroponic. Agrotech J. 3. 21-26.

Biswal A.K. and Kohli A. (2013). Cereal flag leaf adaptations for grain yield under drought: knowledge status and gaps. Flag Leaf Review Revision. 1-35.

Bita C. E. and Gerats T. (2013). Plant tolerance to high temperature in a changing environment: scientific fundamentals and production of heat stress-tolerant crops. Front. Plant Sci. 4. 273.

Bukhat, N.M. (2005). Studies in yield and yield associated traits of wheat (Triticum aestivumL.) genotypes under drought conditions. M.Sc Thesis Department of Agronomy. Sindh Agriculture University, Tandojam, Pakistan.

Daryanto S., Wang L. and Jacinthe P. A. (2016). Global synthesis of drought effects on maize and wheat production. PLOS ONE. 11.1371.

Fahad S., Bajwa A.A., Nazir U., Anjum S.A., Farooq A., Zohaib A., Sadia S., Nasim W., Adkins S., Saud S., Ihsan M.Z., Alharby H., Wu C., Wang D. and Huang J. (2017). Crop Production under Drought and Heat Stress: Plant Responses and Management Options. Front. Plant Sci.8. 1147.

Hsiao T. C. and Xu L.K. (2000). Sensitivity of growth of roots versus leaves to water stress: biophysical analysis and relation to water transport. J. Exp. Bot. 51. 1595-1616.

Huseynova I. M. and Rustamova S. M.
(2010). Screening for drought stress tolerance in wheat genotypes using molecular markers. Institute of Botany, Azerbaijan National Academy of Sciences, 40 Badamdar Shosse, Baku AZ 1073, Azerbaijan. 65. 132-139.

Kalim Ullah S., Khan J., Irfaq M. and Rahman H. U. (2012) Genetic variability, correlation and diversity studies in bread wheat (Triticum aestivum L.) germplasm. J. of Animal \&Plant Sci., 20: 330-333.

Khan N. and Naqvi F. N. (2011). Effect of water stress in bread wheat hexaploids. Curr. Res. J. of Biological Sci.3. 487498.

Kirigwi F.M., Ginkel M.V., Brown-Guedira G., Gill B.S., Paulsen G.M., Fritz A.K. (2007). Markers associated with a QTL for grain yield in wheat under drought. Mol. Breed. 20. 401-413.

Li Y. P., Ye W., Wang M. and Yan X. D.(2009). Climate change and drought: a risk assessment of crop-yield impacts. Clim. Res. 39. 31-46.

Mickelbart M. V., Hasegawa P. M. and Bailey-Serres J. (2015). Genetic mechanisms of abiotic stress tolerance that translate to crop yield stability. Nat. Rev. Genet. 16. 237-251.

Mwadzingeni L., Shimelis H., Dube E., Laing M. D. and Tsilo T. J. (2016) Breeding wheat for drought tolerance: Progress and technologies. Journal of Integrative Agriculture., 5: 935-943.

Pennisi E. (2008). Plant genetics. The blue revolution, drop by drop, gene by gene.Science.320 (5873):171-3.

Ramya P., Chaubal A., Kulkarni K., Gupta L., Kadoo N., Dhaliwal H. S., Chhunejam P., Lagu M. and Gupta V. (2010) QTL mapping of 1000-kernel weight, kernel length, kernel width in bread wheat (Triticum aestivum L.). J. Applied Genetics., 51: 421-429.

Rana M.S., Hasan M.A., Bahadur M.M. and 
Islam M.R. (2017). Effect of Polyethylene Glycol Induced Water Stress on Germination and Seedling Growth of Wheat (Triticum aestivum). The Agriculturists A Scientific Journal of Krishi Foundation. 15. 81-91.

Rauf M., Munir M., Hassan M., Ahmad M. and Afzal M. (2006). Performance of wheat genotypes under osmotic stress at germination and early seedling growth stage. Afr. J. Biotechnol. 6. 971-975.

Saleem M. (2003) Responses of durum and bread wheat genotypes to drought stress: Biomass and yield components. Asian Journal of Plant Science., 2: 290293.

Sanchez-Bragado R., Molero G., Reynolds M.P. and Araus J.L. (2016). Photosynthetic contribution of the ear to grain filling in wheat: a comparison of different methodologies for evaluation J. of Experi. Bot., 67. 2787-2798.

Shao H. B., Liang Z. S., Shao M. A. and Wang B. C. (2005) Changes of some physiological and biochemical indices for soil water deficits among 10 wheat genotypes at seedling stage. Biointerfaces., 42. 113-119.

Shirazi M.U., Khan M.A., Bhatti N., Unar A., Bozdar H.B., Mujtaba S.M. and Lashari
M.I. (2014). Growth and Water use efficiency in wheat genotypes grown under water stress condition. J. of Agri. Res. and Devel. 4. 23-28.

Sokoto M. B. and Singh A. (2013) Yield and Yield Components of Bread Wheat as Influenced by Water Stress, Sowing Date and Cultivar in Sokoto. Sudan Savannah, Nigeria American Journal of Plant Sciences., 4: 122-130

Tabassam M. A. R., Hussain M., Sami A., Shabbir I., Bhutta M. A. N., Muhammad M. and Sarfraz A. (2014). Impact of drought on the growth and yield of wheat, Sci. Agri., 1: 11-18.

Tahir M., Tanveer A., Shah T. H., Fiaz N. and Wasaya A. (2009) Yield Response of Wheat (Triticum aestivum L.) to Boron Application at Different Growth Stages. Pak. J. Life Soc. Sci., 71: 39-42.

Taiz, L. and Zeiger, E. (2006). Plant Physiology. 4th Edition, Sinauer Associates Inc. Publishers, Massachusetts.

Tian Y., Zheng C., Chen J., Chen C. and Deng A. (2014) Climatic Warming Increases Winter Wheat Yield but Reduces Grain Nitrogen Concentration in East China. PLoS ONE., 4: e95108.

\section{How to cite this article:}

Lalit Kumar, Megha Singh and Vaishali Arora. 2020. Influence of Drought Stress on Morphological Characters in Indian Wheat Cultivars. Int.J.Curr.Microbiol.App.Sci. 9(10): 816832. doi: https://doi.org/10.20546/ijcmas.2020.910.098 